\title{
A CASE STUDY OF IDENTIFY IMPORTANCE OF LAND USE PLANNING IN ROAD SAFETY, BENIDORM
}

\author{
Jairo Casares Blanco \\ Civil Engineer, University of Alicante, Spain \\ Juan Carlos Sánchez Galiano \\ Lecturer, Building and Urbanism Department, University of Alicante, Spain \\ Patricia Fernández Aracil \\ $\mathrm{PhD}$ student and researcher, University of Alicante, Spain \\ Armando Ortuño Padilla \\ Associate professor, Building and Urbanism Department, University of Alicante, Spain
}

\section{SUMMARY}

This research analyses how urban form, land use and urban density, may influence the incidence of traffic-related crashes injuries and deaths. It begins with a theoretical overview of studies which deal with the study of the relationship between urban patterns and road safety. Next, it details the development of a database of crash incidence and urban form at the district level for the city of Benidorm (Alicante, Spain) in 2010.

Subsequently, it is developed a negative binomial approach for intra-city motor vehicle crash analysis. One-year crash data for Benidorm (the fourth largest tourism destination of Spain, after Barcelona, Madrid and San Bartolomé de Tirajana, and exclusively tourist-oriented city) are analyzed using a geographic information system (GIS) to generate relevant inputs for the analysis.

In general, the study finds that a strong land use mix results on fewer road accidents, whereas accidents are more common but less severe in areas of high urban density. Finally, pedestrian accidents research showed that rural and low density environment is related to an important road accident numbers unlike tourism-oriented zones, much more safe for them.

Based on these findings, the paper discusses the implications for urban design practice.

\section{INTRODUCTION}

Mobility generates drawbacks which urban planners, traffic engineers and police have to address daily, including congestion and air pollution. One of the most important problems is the incidence of traffic accidents, which implies loss of life, injuries and a lot of property damages. In this sense, since many of the problems faced by the transport system do not come from the transport sector, a more holistic perspective is necessary to integrate decisionmaking process across sectors and to widen the public discourse (Banister, 2008). 
Some studies (Dumbaugh et al., 2009; Ewing et al., 2003; Kim et al., 2006; Millot, 2004; Noland and Quddus, 2004; Scheiner and Holz-Rau, 2011; Wier et al., 2009) found that factors such as land use, population density or urban form, among others, should be considered when evaluating the number of accidents. Since this type of studies have been carried out mainly in English-speaking countries and at a regional scale, the objective of this study has been to contrast the results obtained in those studies with the results obtained in an urban area such as Benidorm (Alicante, Spain) by means of statistical modeling and geographic information system (GIS) data.

Benidorm is located in Alicante province, in the Southeast of Spain, with a population of 69.045 people in 2015 (National Statistics Institute, 2016). The most important activity is tourism; in fact, Benidorm is the fourth city in Spain measured in terms of overnight hotel stays: more than 11 million in 2015 (National Statistics Institute, 2016).

\section{DATA AND METHODS}

In this study, the authors sought to understand the relationship between traffic accidents and urban planning. To carry out the research, it is developed a GIS-based database of crash incidence and urban form for the City of Benidorm, with data (in the year 2010) provided by Police of the City Council of Benidorm. The total number of accidents at Benidorm in 2010 was 502 accidents, each associated with information such as: location (later, georeference), date, hour, typology (crashes involving pedestrians or not), severity of impact (slight injuries or several injuries, because there is no registered traffic related deaths in 2010).

As Noland and Quddus (2004) and Ha and Thill (2011) have shown, geo-referencing crash locations is a key tool in order to find urban factors that impact on crashes. This was made possible by means of the recorded location of an accident by the Police of Benidorm, which can be identified by its $\mathrm{x}$ and $\mathrm{y}$ coordinates, and the precise location of crashes is established by the Levine et al. (1995a; 1995b) procedure. Specific free software GIS was used on this procedure, named gvSIG.

According to the approach used in this study, Benidorm is divided into 54 cells or variable size areas (Fig. 1) and the following criteria have to be met to avoid the information lost in variables:

- Cells dividing intersections with high rate of registered accidents must be avoided.

- Cells must contain similar urban patterns.

- Cells must include, at least, two land use types. 


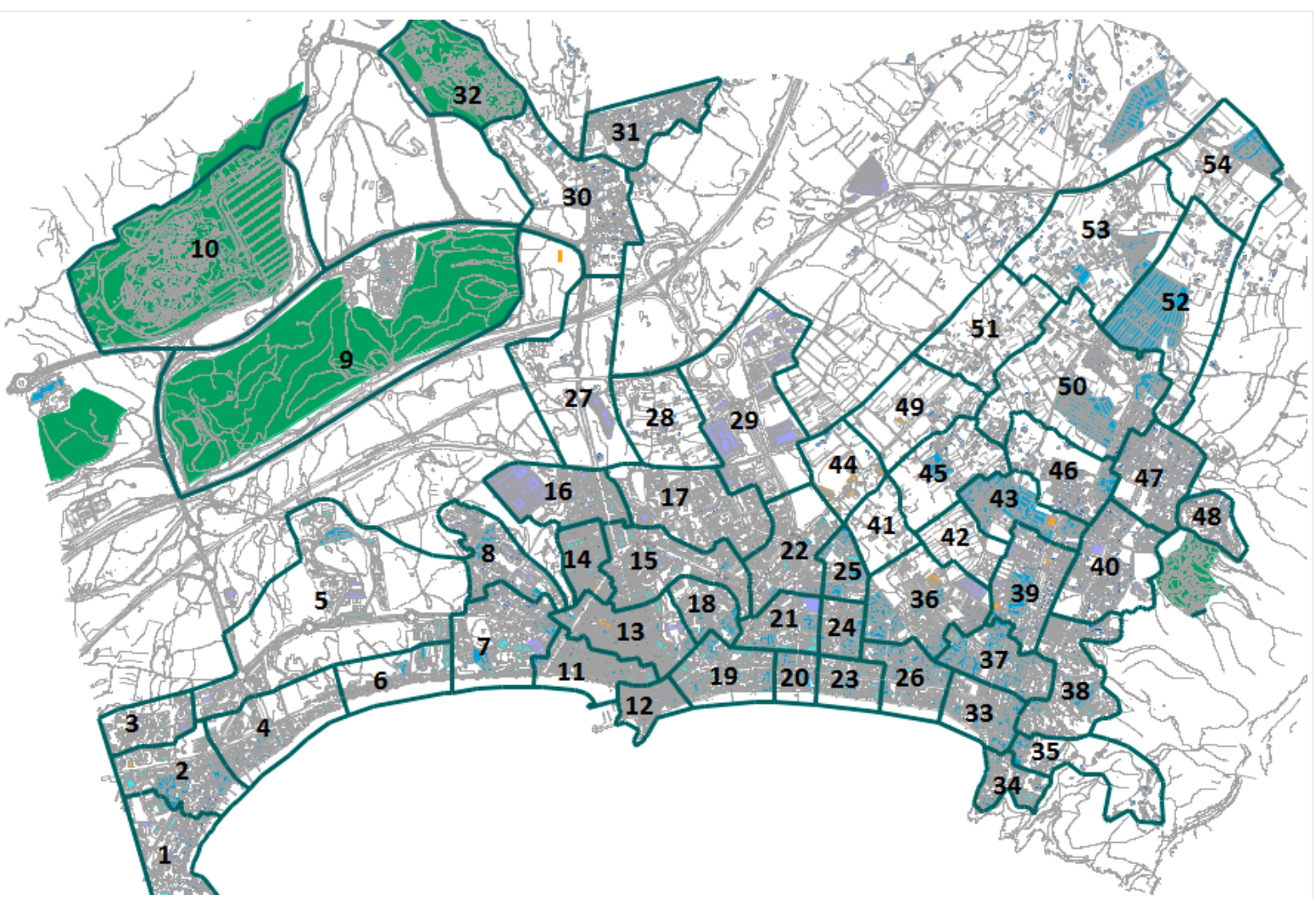

Fig. 1 - Case study area, the city of Benidorm in 2010 and the 54 urban cells

The above-mentioned database of traffic accidents was used in order to establish dependent variables as follows, taking crash severity into account:

- Total registered accidents: Total, with injuries, with slight injuries or with several injuries.

- Only pedestrian accidents: Total, with injuries, with slight injuries or with several injuries.

On the other hand, the following independent variables are going to be included in the models (Table 1), with the aim of develop urban form indicators which could be examined related to their effects on crash incidence, according to Dissanayake et al. (2009) and Wier et al. (2009):

- Entropy index (Eq. 1): Is a measure of land use mix which takes into account the relative percentage of two or more land use types within an area (Song et al., 2013; Turner et al., 2001). Therefore, urban land has been classified into the following uses:

- Residential use: Non-tourism houses, building or similar, including private facilities such as gardens, swimming pools and others.

- Tourism supply use: Tourist accommodation, considering hotels, hostels, apartments or camps, as well as another related tourism amenities.

○ Commercial and retail use: Commercial businesses, non-residential, such as offices, bars, restaurants, retail, etc.

- Institutional use: Public buildings, such as education centres, churches, community centres, etc. 
○ Recreational use: Public amenities or recreational areas, such as parks, gardens or beaches.

- Rural use: Land that has not been built on, without use or protected by municipal legislation.

$$
\text { ENTROPY INDEX }=-\left[\sum_{j=1}^{k} P^{j} \ln \left(P^{j}\right)\right] / \ln (k)
$$

Where $P j$ is the percentage of each land use type $j$ in the cell, and $k$ is be the number of land use types $j$. The maximum entropy index value of 1 can only be achieved by a perfect equal balance of land uses, such as 33.3\% / 33.3\% / 33.3\% and when one land use type dominates, most area will appear similarly low with respect to the entropy index (Song et al., 2013). In order to calculate the different land use areas, the platform GEONET and Directorate General for Property Assessment have been used.

- Population density (inhabitants/ha): Total population was gathered from SánchezGaliano (2013) research, where author obtained total population by means of calculating registered and seasonal population of Benidorm. Seasonal population was estimated from domestic water.

- Roads length (m): arterial ways, local ways and pedestrian streets.

- Junction density: Number of intersections divided by total length of roads within a cell (m).

- Hotel supply: Number of hotel seats, including hotels, hostels, camping and apartments.

\begin{tabular}{|l|r|r|r|r|r|}
\hline Variable & Obs. & Maximum & Minimum & Standard deviation & Average \\
\hline Entropy index & 54 & 0.996 & 0.256 & 0.186 & 0.651 \\
\hline Log density & 54 & 2.646 & 0.000 & 0.878 & 1.646 \\
\hline Log arterial & 54 & 3.387 & 0.000 & 1.391 & 1.923 \\
\hline Log local & 54 & 3.738 & 0.000 & 0.999 & 2.907 \\
\hline Log pedestrian & 54 & 3.231 & 0.000 & 1.223 & 0.777 \\
\hline Log rural & 54 & 3.654 & 0.000 & 1.481 & 1.103 \\
\hline Junction density & 54 & 0.011 & 0.001 & 0.002 & 0.005 \\
\hline Log hotel supply & 54 & 3.743 & 0.000 & 1.504 & 2.108 \\
\hline
\end{tabular}

Table 1 - Descriptive statistics.

\section{CAlCulation}

Crashes are discrete events and this sort of count-data is generally analysed using a number of methods including the Poisson, the Negative Binomial and Multivariate Modelling (Lord and Mannering, 2010). The Negative Binomial Model was selected in this study due to its applicability to overcome over-dispersion in the data (the variance exceeds the mean of the crash counts). 
The natural logarithm from the independent variables has been taken (except for entropy index and junction density), due to the skewed distribution, and the software used for the econometric calculation was R-Package.

\section{RESULTS AND DISCUSSION}

Estimation results are tabulated in Table 2 and Table 3, which presents the outcome of the study through eight different equations (eight dependent variables). Table 2 exposes the results of the total crashes models, whereas Table 3 presents the results of only pedestrian accidents models.

\begin{tabular}{|l|r|r|r|r|}
\hline \multirow{2}{*}{$\begin{array}{c}\text { Independent } \\
\text { variables }\end{array}$} & \multicolumn{4}{|c|}{ Dependent variables } \\
\cline { 2 - 5 } Constant & Total accidents & Total injuries & $\begin{array}{c}\text { Total slight } \\
\text { injuries }\end{array}$ & $\begin{array}{c}\text { Total several } \\
\text { injuries }\end{array}$ \\
\hline \multirow{2}{*}{ Entropy index } & -0.206 & -0.912 & $-1.406 \cdot$ & $-5.118^{*}$ \\
& $(-0.281)$ & $(-0.961)$ & $(-1.697)$ & $(-2.268)$ \\
\hline \multirow{2}{*}{ Log density } & $-1.849^{*}$ & $-1.879 \cdot$ & $-1.63 \cdot$ & 0.366 \\
& $(-2.066)$ & $(-1.658)$ & $(-1.727)$ & $(0.186)$ \\
\hline \multirow{2}{*}{ Log arterial } & $0.661^{*}$ & 0.481 & $0.883^{* *}$ & 0.548 \\
& $(2.333)$ & $(1.287)$ & $(2.792)$ & $(0.772)$ \\
\hline \multirow{2}{*}{ Log local } & $0.742^{* * *}$ & $0.910^{* * *}$ & $0.854^{* * *}$ & $0.835^{* *}$ \\
& $(7.283)$ & $(5.954)$ & $(6.842)$ & $(2.680)$ \\
\hline \multirow{2}{*}{ Log pedestrian } & 0.18 & 0.082 & 0.179 & 0.385 \\
& $(1.195)$ & $(0.441)$ & $(1.068)$ & $(0.746)$ \\
\hline \multirow{2}{*}{ Log rural } & 0.162 & 0.016 & $0.179 \cdot$ & -0.638 \\
& $(1.587)$ & $(0.129)$ & $(1.683)$ & $(-0.293)$ \\
\hline \multirow{2}{*}{ Junction density } & -0.035 & -0.095 & 0.083 & -0.059 \\
& $(-0.306)$ & $(-0.622)$ & $(0.675)$ & $(-0.207)$ \\
\hline Log hotel supply & 0.701 & 63.148 & 1.730 & 122.690 \\
& $(0.011)$ & $(0.806)$ & $(0.027)$ & $(0.955)$ \\
\hline
\end{tabular}

Table 2 - Results of the total crashes models (z-statistics in parentheses). (***) Significant at 0.001 level; (**) Significant at 0.01 level; (*) Significant at 0.05 level; (•) Significant at 0.1 level.

The factors associated with total crashes are largely part similar to those influencing only pedestrian accidents, with exceptions. On the one hand, a stronger mix of land uses in the city of Benidorm reduces total road accidents, road accidents with injuries and with slight injuries. On the other hand, the increase in urban density and length of arterial roads impacts on an increase in total accidents. In fact, significance of arterial ways (as opposed to local ways) means that the commuters who cross city live in lower-density bedroom communities and work in higher-density central areas increase its crash risk. 


\begin{tabular}{|c|c|c|c|c|}
\hline variables & $\begin{array}{c}\text { Total } \\
\text { pedestrian } \\
\text { accidents }\end{array}$ & $\begin{array}{c}\text { Pedestrian } \\
\text { injuries }\end{array}$ & $\begin{array}{c}\text { Pedestrian } \\
\text { slight injuries }\end{array}$ & $\begin{array}{c}\text { Pedestrian } \\
\text { several } \\
\text { injuries }\end{array}$ \\
\hline Constant & $\begin{array}{r}-6.218 * * * \\
(-4.193)\end{array}$ & $\begin{array}{r}-8.528 * * * \\
(-3.608)\end{array}$ & $\begin{array}{r}-9.407 * * * * \\
(-3.801)\end{array}$ & $\begin{array}{r}-5.645 \\
(-1.333)\end{array}$ \\
\hline $\begin{array}{l}\text { Entropy } \\
\text { Index }\end{array}$ & $\begin{array}{r}0.461 \\
(0.380)\end{array}$ & $\begin{array}{r}-0.216 \\
(-0.140)\end{array}$ & $\begin{array}{r}0.419 \\
(0.279)\end{array}$ & $\begin{array}{r}1.390 \\
(0.446)\end{array}$ \\
\hline Log density & $\begin{array}{r}2.210^{* * * *} \\
(4.479) \\
\end{array}$ & $\begin{array}{r}2.773 * * * \\
(4.410) \\
\end{array}$ & $\begin{array}{r}2.986 * * * \\
(4.645) \\
\end{array}$ & $\begin{array}{r}1.232 \\
(0.931) \\
\end{array}$ \\
\hline Log arterial & $\begin{array}{r}0.535^{* * * *} \\
(3.803)\end{array}$ & $\begin{array}{r}0.757 * * * \\
(3.757)\end{array}$ & $\begin{array}{r}0.740 * * * \\
(3.428)\end{array}$ & $\begin{array}{r}0.754 \cdot \\
(1.820)\end{array}$ \\
\hline Log local & $\begin{array}{r}0.239 \\
(0.737)\end{array}$ & $\begin{array}{r}0.639 \\
(1.139)\end{array}$ & $\begin{array}{r}0.690 \\
(1.175)\end{array}$ & $\begin{array}{r}-0.293 \\
(-0.352)\end{array}$ \\
\hline $\begin{array}{l}\text { Log } \\
\text { pedestrian }\end{array}$ & $\begin{array}{r}0.139 \\
(1.060) \\
\end{array}$ & $\begin{array}{r}0.090 \\
(0.570) \\
\end{array}$ & $\begin{array}{r}0.138 \\
(0.902) \\
\end{array}$ & $\begin{array}{r}-0.114 \\
(-0.332) \\
\end{array}$ \\
\hline Log rural & $\begin{array}{r}0.442 * * \\
(3.036)\end{array}$ & $\begin{array}{r}0.463 * * \\
(2.604)\end{array}$ & $\begin{array}{r}0.520 * * * \\
(3.325)\end{array}$ & $\begin{array}{r}-0.384 \\
(-0.589)\end{array}$ \\
\hline $\begin{array}{l}\text { Junction } \\
\text { density }\end{array}$ & $\begin{array}{r}79.626 \\
(1.058) \\
\end{array}$ & $\begin{array}{r}4.230 \\
(0.046) \\
\end{array}$ & $\begin{array}{r}-97.790 \\
(-1.042) \\
\end{array}$ & $\begin{array}{r}260.470 \\
(1.443) \\
\end{array}$ \\
\hline $\begin{array}{l}\text { Log hotel } \\
\text { supply }\end{array}$ & $\begin{array}{c}-0.316^{*} \\
(-2.471)\end{array}$ & $\begin{array}{l}-0.384 * \\
(-2.554)\end{array}$ & $\begin{array}{l}-0.350 * \\
(-2.322)\end{array}$ & $\begin{array}{r}-0.520 \\
(-1.837)\end{array}$ \\
\hline
\end{tabular}

Table 3 - Results of the pedestrian accidents models (z-statistics in parentheses). (***) Significant at 0.001 level; $(* *)$ Significant at 0.01 level; (*) Significant at 0.05 level; (•) Significant at 0.1 level.

According to Table 3, urban density and roads length (arterial and rural) are positively associated with total pedestrian accidents, while the hotel supply are noted to have a negative relationship with pedestrian accidents of different severities.

In Benidorm, $70 \%$ of population live on cells with an urban density up to 200 inhabitants per hectare, which could be an explanatory factor of this unexpected result associated to density, nevertheless our data did not permit an in-depth analysis of the reasons for this finding. The effects of urban density are due also to reasons other than the urban form itself, for example behaviour, road design or risk exposure.

With respect to total rural roads length variable, the results proves that pedestrian road accidents increase in rural environment of arterial roads, specifically due to the lack of pedestrian infrastructures segregated from road traffic on accesses of arterial roads in Benidorm.

To conclude discussion of results, one of the most remarkable results on this research is the effect of the significance of hotel supply (hotel, hostel, camping and apartments) related to pedestrian road safety. This research demonstrates that tourism-oriented urbanism has a positive impact on pedestrian road safety.

\section{CONCLUSIONS}

This paper presented geographical and statistical analyses of urban road accidents based on the tourist-oriented city of Benidorm. 
Results show that entropy index, which quantifies the level of mix of urban land uses, is negatively related to road accidents, verifying the hypothesis that urban developments with strong mix of land uses minimize the number of road accidents and number of injuries.

On the other hand, because some commuters who cross city live in lower-density bedroom communities and work in higher-density central areas, it has been observed a positive close relation between pedestrian road accidents and presence of arterial and collector roads, largely due to the lack of pedestrian infrastructure on arterial access roads of Benidorm.

With respect to density, the absence of big areas with urban low density in the city of Benidorm determines population density variable remains positively related with road accidents, but shall not be considered that medium-high density residents suffer from more road accidents.

Finally, the study shows that there are a lower number of pedestrian road accidents and injuries in tourism-oriented planning zones of Benidorm city. This is the first study for Spain that relates road accidents to urban factors including hotel supply, but further research is required in terms of other case studies in various spatial contexts in order to provide a more comprehensive understanding and improve the knowledge of urban factors contributing reduce accidents.

\section{ACKNOWLEDGMENTS}

Authors wish to acknowledge City Council of Benidorm for sharing databases and the Office of the Vice President for Research, Development and Innovation of University of Alicante within Programa Propio to encourage R\&D\&I, which beneficiary is the co-author Patricia Fernández Aracil.

\section{REFERENCES}

BANISTER, D. (2008). The sustainable mobility paradigm. Transport Policy, 15, 73-80.

DIRECTORATE GENERAL FOR PROPERTY ASSESMENT. (2014). http://www.catastro.meh.es/

DISSANAYAKE, D., ARYAIJA, J. and WEDAGAMA, P. (2009). Modelling the effects of land use and temporal factors on child pedestrian casualties. Accident Analysis and Prevention, 41, 1016-1024.

DUMBAUGH, E., RAE, R. and WUNNEBERGER, D. (2009). Examining the relationship between Community Design and Crash Incidence. Southwest Region University Transportation Center, Texas Transportation Institute Texas A\&M University System College Station, Texas.

EWING, R., SCHIEBER, R. and ZEGEER, C. (2003). Urban sprawl as a risk factor in motor vehicle occupant and pedestrian fatalities. American Journal of Public Health, 93(9), 15411545 .

GEONET. (2014). http://www.geonet.es/es/

HA, H. and THILL, J.C. (2011). Analysis of traffic hazard intensity: A spatial epidemiology 
case study of urban pedestrians. Computers, Environment and Urban Systems, 35, 230-240.

KIM, K., BRUNNER, I.M. and YAMASHITA, E.Y. (2006). Influence of land use, population, employment, and economic activity on accidents. Transportation Research Record: Journal of the Transportation Research Board, $\mathrm{n}^{\circ}$ 1953, 56-64.

LEVINE, N., KIM, K.E. and NITZ, L.H. (1995a). Spatial analysis of Honolulu motor vehicle crashes: I. Spatial patterns. Accident Analysis \& Prevention, 27(5), 663-674.

LEVINE, N., KIM, K.E. and NITZ, L.H. (1995b). Spatial analysis of Honolulu motor vehicle crashes: II. Zonal generators. Accident Analysis \& Prevention, 27(5), 675-685.

LORD, D. and MANNERING, F. (2010). The statistical analysis of crash-frequency data: A review and assessment of methodological alternatives. Transportation Research Part A, 44, 291-305.

MILLOT, M. (2004). Urban growth, travel practices and evolution of road safety. Journal of Transport Geography, 12(3), 207-218.

NATIONAL INSTITUTE OF STATISTICS. (2016). http://www.ine.es

NOLAND, R.B. and QUDDUS, M. A. (2004). A spatially disaggregate analysis of road casualties in England. Accident Analysis \& Prevention, 43(1), 307-322.

SÁNCHEZ-GALIANO, J.C. (2013). Estudio de la población estacional en áreas turísticas. Estudio de caso: Benidorm. Universidad de Alicante.

SCHEINER, J. and HOLZ-RAU, C. (2011). A residential location approach to traffic safety: two case studies from Germany. Accident Analysis \& Prevention, 43(1), 307-322.

SONG, Y., MERLIN, L. and RODRÍGUEZ, D. (2013). Comparing measures of urban land use mix. Computers, Environment and Urban Systems, 42, 1-13.

TURNER, M.G., GARDNER, R.H. and O'Neill, R.V. (2001). Landscape ecology in theory and practice: Pattern and process. New York, Springer.

WIER, M., WEINTRAUB, J., HUMPHREYS, E.H., SETO, E. and BHATIA, R. (2009). An area-level model of vehicle-pedestrian injury collisions with implications for land use and transportation planning. Accident Analysis and Prevention, 41(1), 137-145. 